\title{
Editorial
}

\section{Educação é sempre o início e o maior bem}

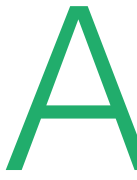

partir do trabalho científico de qualidade, com a colaboração dos revisores e de todos os demais que a possibilitam, tem-se aqui mais um fascículo da RBAV. Nesse exemplar será possível verificar a grande variedade de assuntos que sempre foi o lema da nossa revista, além da diversidade na formação das pessoas que aqui publicam. Assim, temos trabalhos de pesquisadores experientes e também a presença de artigos de pessoas que estão iniciando a jornada acadêmica. Todos com a criteriosa avaliação do corpo editorial desta Revista. Além disso, é com prazer que recebemos o artigo de Aline Paschoal e colegas, primeiro lugar no CECEMM; afinal, a educação é sempre o início e o maior bem que podemos ter. É sempre pertinente lembrar a firme atuação do Prof. Ross Douglas, que insistia na participação dos estudantes, em colaboração com os professores e pesquisadores, em todas as atividades da Sociedade Brasileira de Vácuo. Aguardamos novos artigos e a contínua participação de todos, para que as atividades da SBV continuem a propiciar a divulgação da Ciência.

Álvaro Jose Damião

Antonio Renato Bigansolli

Maria Lúcia Pereira da Silva

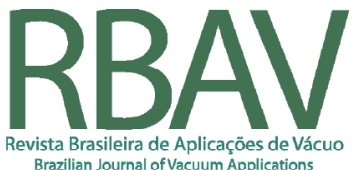

